\title{
PENERAPAN SISTEM INFORMASI AUDIT MUTU INTERNAL BERBASIS WEB GUNA MENINGKATKAN EFISIENSI KERJA STUDI KASUS: LEMBAGA PENJAMINAN MUTU UNIVERSITAS BUDI LUHUR
}

\author{
Dwi Rani Febriyanti ${ }^{1)}$, Hendri Irawan ${ }^{2)}$ \\ ${ }^{1}$ Sistem Informasi, Fakultas Teknologi Informasi, Universitas Budi Luhur \\ ${ }^{1,2} \mathrm{Jl}$. Raya Ciledug, Petukangan Utara, Kebayoran Lama, Jakarta Selatan 12260 \\ E-mail : dwirani665@gmail.com ${ }^{1)}$, hendri.irawan@budiluhur.ac.id ${ }^{2)}$
}

\begin{abstract}
Abstrak
Audit mutu internal merupakan salah satu persyaratan yang harus dipenuhi oleh perguruan tinggi, sebagai bentuk refleksi evaluasi diri, yang dilakukan oleh institusi tersebut. Universitas Budi Luhur sebagai institusi pendidikan telah melakukan peningkatan dalam penerapan ISO (The International Organization for Standardization), oleh United Registrar of Systems Limited (URS Certification), untuk audit mutu. Dalam menjalani audit internal, masih terdapat sejumlah permasalahan yang terjadi di Lembaga Penjaminan Mutu Universitas Budi Luhur. Mulai dari masih ditemukan ketidaksesuaian dalam menentukan jenis temuan audit oleh auditor, hingga penyelesaian laporan audit mutu internal yang tidak dapat diselesaikan tepat waktu. Penelitian ini bertujuan untuk membangun sebuah sistem informasi berorientasi obyek untuk audit mutu internal berbasis web menggunakan bahasa pemrograman PHP dan XAMPP yang digunakan sebagai aplikasi web server apache yang terintegrasi dengan MySQL sebagai databasenya, yang dapat mengatasi semua permasalahan yang ditemukan pada Lembaga Penjaminan Mutu Universitas Budi Luhur. Hasil penelitian ini dapat membantu efisiensi dalam proses audit internal seperti daftar periksa, temuan audit, resume audit dan dapat membantu ketepatan waktu dalam penyelesaian laporan audit mutu internal pada Lembaga Penjaminan Mutu Universitas Budi Luhur.
\end{abstract}

Kata kunci: Audit Mutu Internal, audit internal, web, PHP, XAMPP

\section{PENDAHULUAN}

Audit Mutu Internal yang disingkat menjadi AMI, dimaksudkan untuk meninjau tingkat kesesuaian dan efektivitas penerapan Sistem Manajemen Mutu (SMM), yang telah ditetapkan dan menjadi dasar arah strategi dan sasaran mutu perguruan tinggi, yang ingin dicapai dan tertuang dalam manual mutu.

Universitas Budi Luhur sebagai institusi pendidikan telah melakukan peningkatan dalam penerapan ISO (The International Organization for Standardization), oleh United Registrar of Systems Limited (URS Certification), untuk audit mutu. Jenis standar ISO yang diterapkan adalah ISO 9001 yang bertujuan untuk meningkatkan efektivitas manajemen mutu. Sejak tahun 2004 Lembaga Penjaminan Mutu Universitas Budi Luhur telah menerapkan versi ISO 9001:2000, kemudian pada tahun 2010 diterapkan versi ISO 9001:2008 dan mengalami perubahan pada tahun 2018 menjadi versi ISO 9001:2015, sampai saat ini di tahun 2019.

Penerapan ISO 9001:2015 menjadi penting untuk dipahami pegiat manajemen mutu, karena klausul yang diberikan lebih rapi dan terstruktur, serta berbasis pada manajemen resiko dengan konsep PDCA atau Plan-Do-Check-Action.
Dalam menjalani audit internal, masih terdapat sejumlah permasalahan yang terjadi di Lembaga Penjaminan Mutu Universitas Budi Luhur. Masih ditemukan ketidaksesuaian dalam menentukan jenis temuan audit oleh auditor. Hal ini disebabkan karena tidak sedikit auditor yang belum paham terhadap jenis temuan audit, mengakibatkan staf bidang monitoring dan audit mutu memperbaiki dalam menentukan jenis temuan audit tapi tidak sepenuhnya. Selain itu, ketepatan waktu dilanggar dalam melakukan daftar periksa, karena terkadang fakultas ataupun unit belum menyiapkan semua dokumen yang dibutuhkan auditor, mengakibatkan proses audit internal menjadi lama. Penyelesaian laporan audit mutu internal menjadi tidak tepat waktu, karena lamanya pengiriman semua dokumen dari proses audit internal kepada staf bidang monitoring dan audit mutu, mengakibatkan rapat evaluasi dengan auditor menjadi tertunda. Selama ini dalam proses audit internal seperti daftar periksa, temuan audit, resume audit masih bersifat manual. Setelah semua dokumen sudah diserahkan kepada staf bidang monitoring dan audit mutu, kemudian staf tersebut membuat laporan audit mutu internal menggunakan Microsoft Word dan Microsoft Excel.

Tujuan peneliti adalah membuat sistem informasi audit mutu internal berbasis web yang 
dapat mengatasi semua permasalahan yang ditemukan pada Lembaga Penjaminan Mutu Universitas Budi Luhur. Selain itu, menyediakan fitur jenis temuan audit dan terhindar dari ketidaksesuaian dalam menentukan jenis temuan audit, menghadirkan fitur daftar periksa dan resume audit untuk mempercepat proses audit internal dan memudahkan staf bidang monitoring dan audit mutu dalam membuat laporan audit mutu internal dan penyelesaian laporan menjadi tepat waktu.

Terdapat referensi teori-teori tentang analisa dan perancangan sistem informasi berorientasi obyek yang berkaitan dengan penelitian sebagai berikut:

Analisis sistem dan kaitannya dengan sebuah konsep dasar analisa dan perancangan adalah: "Suatu proses untuk memahami sistem yang ada, dengan menganalisa jabatan dan uraian tugas (business users), proses bisnis (business process), ketentuan atau aturan (business rule), masalah dan mencari solusinya (business problem and solution), business tools dan rencana-rencana perusahaan (business plans)”. [1]

Perancangan sistem dan kaitannya dengan sebuah konsep dasar analisa dan perancangan adalah: "Upaya untuk mengonstruksi sebuah sistem yang memberikan kepuasan (mungkin informal) akan spesifikasi kebutuhan fungsional, memenuhi target, memenuhi kebutuhan secara implisit atau eksplisit dari segi kinerja maupun penggunaan sumber daya, kepuasan batasan pada proses desain dari segi biaya, waktu, dan perangkat. Kualitas perangkat lunak biasanya dinilai dari segi kepuasan pengguna perangkat lunak terhadap perangkat lunak yang digunakan”. [2]

Analisa berorientasi obyek atau Object Oriented Analysis adalah: "Metode Analisis yang memeriksa kebutuhan yang harus dipenuhi sebuah sistem dari sudut pandang kelas-kelas dan objekobjek yang ditemui dalam ruang lingkup perusahaan”. [3]

\section{PENELITIAN SEBELUMNYA}

Terdapat beberapa jurnal yang dipelajari oleh peneliti yang berkaitan dengan penelitian, yaitu:

Penelitian tentang Rancang Bangun Aplikasi Audit Mutu Akademik Internal Universitas Sam Ratulangi Berbasis Web. Hasil dari penelitian ini yakni, membangun aplikasi pengauditan yang bisa membantu tim auditor Universitas Sam Ratulangi dalam pengauditan di setiap jurusan yang ada melalui web. Selain itu dengan adanya aplikasi ini dapat membantu tim pengaudit Universitas Sam Ratulangi menjadi lebih efisien. [4]

Penelitian tentang Rancang Bangun Sistem Informasi Penjaminan Mutu Perguruan Tinggi
Menggunakan Metode Throwaway Prototyping Development. Membahas proses audit mutu internal yang dilakukan dengan sistem informasi penjaminan mutu yang dapat mempermudah pengumpulan data untuk pengisian borang akreditasi BAN-PT dan memberikan informasi data yang tepat pada setiap unit di perguruan tinggi. [5]

Penelitian tentang Peningkatan Kualitas Evaluasi Mutu Akademik Universitas Muhammadiyah Malang melalui Sistem Informasi Mutu (SIMUTU). Hasil dari penelitian ini dapat membantu prosedur pengaturan instrumen evaluasi, sehingga instrumen evaluasi dapat diubah dan ditingkatkan pada tiap periode evaluasi. Penelitian ini juga akan mengoptimasi prosedur analisis sehingga proses evaluasi menjadi lebih ringkas dan tidak membutuhkan personil analisis seperti pada pelaksanaan evaluasi secara manual. [6]

\section{METODE PENELITIAN}

Metode penelitian merupakan sekumpulan kegiatan yang dilakukan oleh peneliti.

Metode penelitian dapat dijabarkan pada gambar 1 tahapan penelitian sebagai berikut:

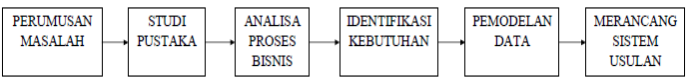

Gambar 1. Tahapan Penelitian

Terdapat beberapa tahapan penelitian yang dilakukan adalah sebagai berikut:

Perumusan masalah merupakan tahapan inisialisasi dari kegiatan penelitian terhadap permasalahan yang dihadapi oleh Lembaga Penjaminan Mutu Universitas Budi Luhur. Hasil dari identifikasi masalah pada proses bisnis berjalan digambarkan dengan fishbone diagram, dimana pada diagram tersebut akan terlihat sebab akibat terjadinya masalah. Metode pengumpulan data untuk memahami masalah, diantaranya yaitu: wawancara, pengumpulan data dilakukan dengan cara bertatap muka langsung dengan mengajukan beberapa pertanyaan mengenai proses bisnis yang sedang berjalan kepada kepala bidang monitoring dan audit mutu, maupun staf bidang monitoring dan audit mutu.

Penelitian ini melakukan studi kepustakaan dari berbagai buku yang terbit paling lama 7 tahun terakhir serta referensi jurnal yang telah terpublikasi dan terbit 5 tahun terakhir.

Menganalisa proses bisnis berjalan, mengidentifikasi masalah pada Lembaga Penjaminan Mutu Universitas Budi Luhur berdasarkan hasil wawancara dan dokumen yang 
berkaitan, yang kemudian digambarkan ke dalam activity diagram.

Hasil dari identifikasi kebutuhan digambarkan dengan menggunakan model sistem dengan use case diagram.

Pemodelan data digambarkan dengan Entity Relationship Diagram (ERD).

Merancang sistem usulan dengan membangun real system untuk audit mutu internal berbasis web pada Lembaga Penjaminan Mutu Universitas Budi Luhur.

\section{HASIL DAN PEMBAHASAN}

Melalui visinya yaitu menjadi unit yang unggul dalam peningkatan standar mutu sistem pendidikan tinggi di Universitas Budi Luhur yang ditopang teknologi informasi dan komunikasi, Lembaga Penjaminan Mutu Universitas Budi Luhur selalu berkomitmen menjaga agar mutu proses pendidikan berjalan sesuai dengan standar nasional perguruan tinggi. Terbentuk sejak bulan juni tahun 2004 berawal dengan nama unit yaitu Biro Kendali Mutu. Pada tahun 2006 berubah nama menjadi Direktorat Penjaminan Mutu, di tahun 2008 dengan perubahan nama unit yaitu Biro Kendali Mutu. Kemudian di tahun 2010 berubah nama menjadi Lembaga Penjaminan Mutu, di tahun 2013 dengan perubahan nama unit yaitu Direktorat Riset dan Penjaminan Mutu. Pada tahun 2018 berubah nama menjadi Lembaga Penjaminan Mutu sampai dengan saat ini. Pergantian nama unit dikarenakan terjadi penyesuaian dengan adanya pergantian struktur organisasi dalam kurun waktu 4 (empat) tahun sekali. Misi Lembaga Penjaminan Mutu Universitas Budi Luhur melaksanakan siklus Sistem Penjaminan Mutu Internal (SPMI) secara terencana dan berkelanjutan, mendukung kesiapan institusi dan program studi dalam pelaksanaan Sistem Penjaminan Mutu Eksternal (SPME), melaksanakan sistem penanganan keluhan pelanggan secara efektif dan efisien dan melaksanakan pengembangan dan inovasi sistem penjaminan mutu berbasis teknologi informasi dan komunikasi.

Dalam analisa proses bisnis digambarkan dengan Activity diagram. Activity diagram adalah: "Activity diagram menggambarkan aliran kerja atau aktivitas dari sebuah sistem atau proses bisnis bagaimana masing-masing alir berawal, activity diagram menggambarkan aktivitas sistem bukan apa yang dilakukan oleh aktor”.

Terdapat beberapa analisa proses bisnis yang digambarkan dengan 3 (tiga) Activity diagram sebagai berikut:

a. Activity Diagram Persiapan Audit

Pada gambar 2 Activity Diagram Persiapan Audit, admin menyiapkan daftar periksa, daftar temuan dan resume audit. Admin mengkonfirmasi rencana audit dan memastikan tidak ada perubahan waktu. Bila ada perubahan, auditee menentukan kembali waktu pengganti audit.

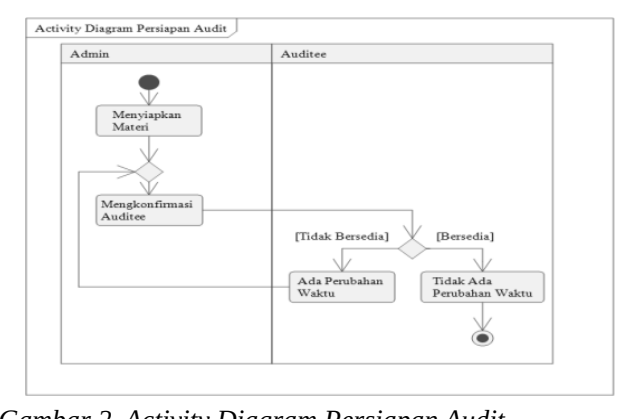

Gambar 2. Activity Diagram Persiapan Audit

b. Activity Diagram Pelaksanaan Audit

Pada gambar 3 Activity Diagram Pelaksanaan Audit, admin mengadakan rapat sebelum auditor melaksanakan audit. Auditor melakukan tanyaamati-periksa secara proporsional dan menuliskan pada form-form audit. Auditor menyampaikan klasifikasi temuan.

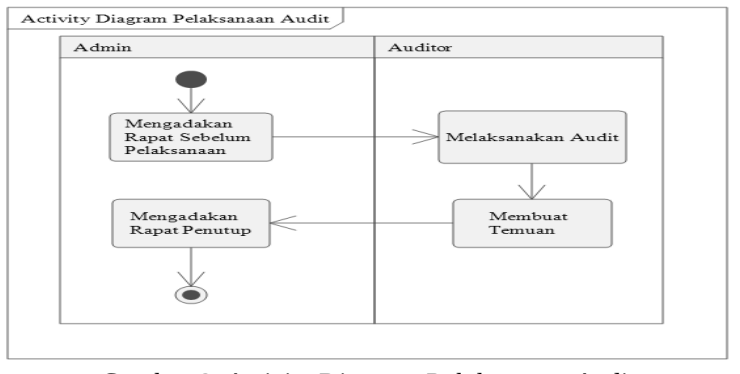

Gambar 3. Activity Diagram Pelaksanaan Audit

\section{c. Activity Diagram Verifikasi Audit}

Pada gambar 4 Activity Diagram Verifikasi Audit, auditor mengidentifikasi temuan dan menyepakati temuan yang akan ditindaklanjuti pada batas waktu tindakan koreksi untuk verifikasi dengan auditee. Auditor melakukan tanya-amatiperiksa temuan-temuan yang dilakukan tindakan perbaikan. Bila verifikasi tindakan koreksi sudah sesuai, maka kasus temuan ditutup dan auditor melengkapi laporan audit.

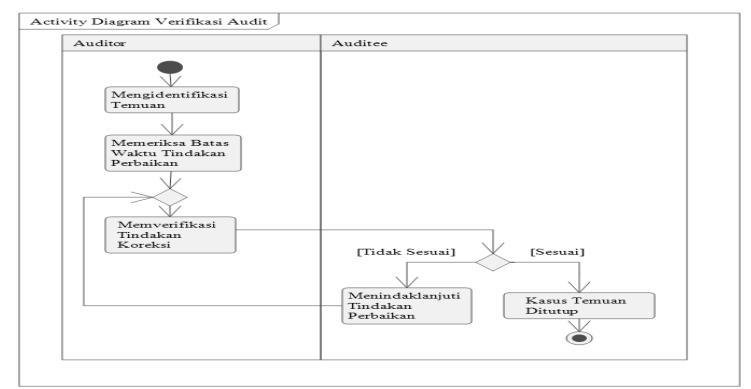

Gambar 4. Activity Diagram Verifikasi Audit 
Menganalisa permasalahan yang sedang dihadapi, peneliti menggunakan diagram untuk membantu dalam pemetaan masalah. "Diagram ishikawa atau Fishbone Diagram merupakan sebuah diagram yang digunakan untuk mengidentifikasi penyebab dan efek masalah”. [7]

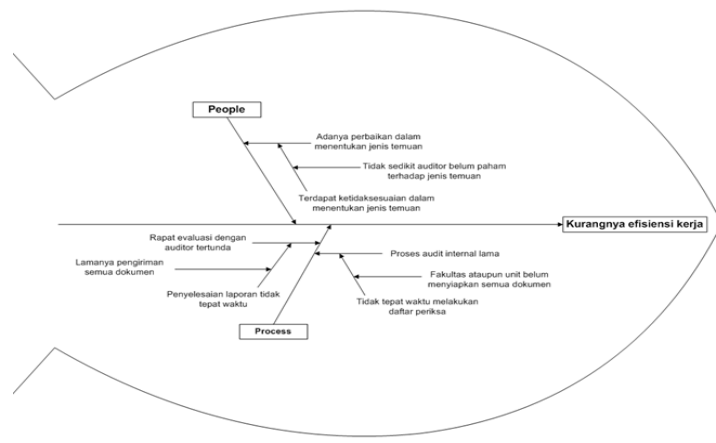

Gambar 5. Activity Diagram Fishbone Diagram

Berikut penjelasan pada gambar 5 Fishbone Diagram adalah sebagai berikut:

1) Faktor People :

Masih ditemukan ketidaksesuaian dalam menentukan jenis temuan audit oleh auditor. Hal ini disebabkan karena tidak sedikit auditor yang belum paham terhadap jenis temuan audit, mengakibatkan staf bidang monitoring dan audit mutu memperbaiki dalam menentukan jenis temuan audit tapi tidak sepenuhnya.

2) Faktor Process :

Ketepatan waktu dilanggar dalam melakukan daftar periksa, karena terkadang fakultas ataupun unit belum menyiapkan semua dokumen yang dibutuhkan auditor, mengakibatkan proses audit internal menjadi lama.

Penyelesaian laporan audit mutu internal menjadi tidak tepat waktu, karena lamanya pengiriman semua dokumen dari proses audit internal kepada staf bidang monitoring dan audit mutu, mengakibatkan rapat evaluasi dengan auditor menjadi tertunda.

Dalam identifikasi kebutuhan menggunakan model sistem yang digambarkan dengan use case diagram. Use case diagram merupakan permodelan untuk menggambarkan kelakuan terhadap sistem yang akan dibuat, serta mendeskripsikan interaksi antara satu atau lebih aktor.

Terdapat beberapa model sistem yang digambarkan dengan 7 (tujuh) use case diagram sebagai berikut:

a) Use Case Diagram Package Account

Pada gambar 6 Use Case Diagram Package Account terdapat Login. Adapun actor pada Use Case Diagram Package Account yaitu ketua, kepala bidang monitoring dan audit mutu, staf bidang monitoring dan audit mutu, auditor.

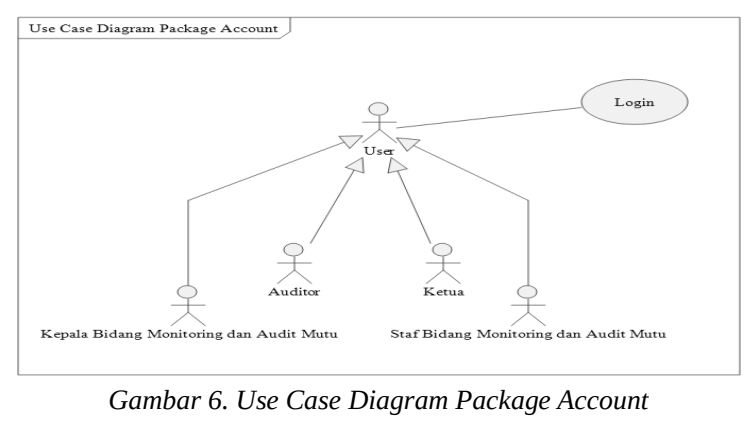

b) Use Case Diagram Package Master

Pada gambar 7 Use Case Diagram Package Master terdapat Entry Auditee, Entry Sub Bagian, Entry Acuan Jenis Temuan, Entry Periode, Entry User, Entry Team Auditor, View Team Auditor by Periode, View Acuan Jenis Temuan. Adapun actor pada Use Case Diagram Package Master yaitu Admin yang terdiri dari ketua, kepala bidang monitoring dan audit mutu, staf bidang monitoring dan audit mutu. Selain itu actor pada Use Case Diagram Package Master yaitu Auditor.

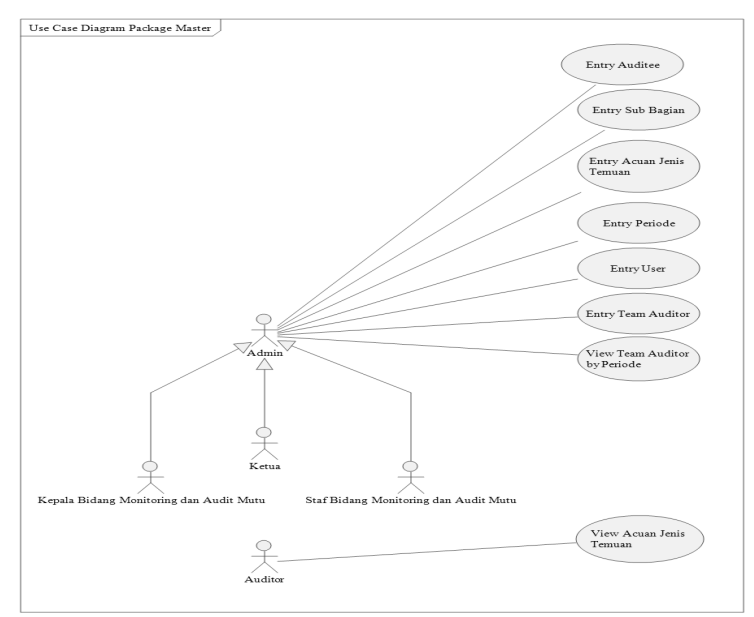

Gambar 7. Use Case Diagram Package Master

c) Use Case Diagram Package Berita Acara Pada gambar 8 Use Case Diagram Package Berita Acara terdapat Entry Berita Acara, View Berita Acara, Cetak Berita Acara. Adapun actor pada Use Case Diagram Package Berita Acara yaitu Admin dan Auditor.

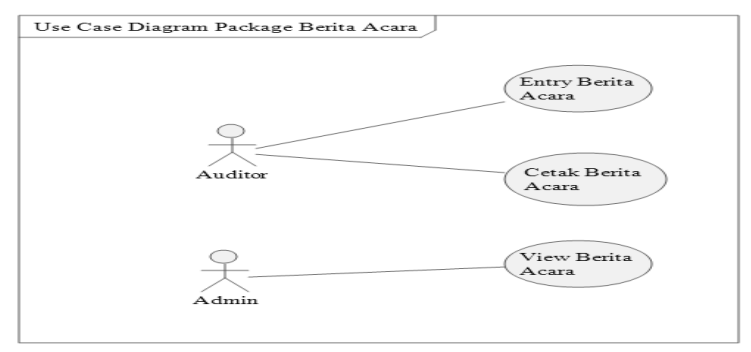

Gambar 8. Use Case Diagram Package Daftar Periksa 
d) Use Case Diagram Package Daftar Periksa Pada gambar 9 Use Case Diagram Package Daftar Periksa terdapat Entry Daftar Periksa, View Daftar Periksa, Cetak Daftar Periksa. Adapun actor pada Use Case Diagram Package Daftar Periksa yaitu Admin dan Auditor.

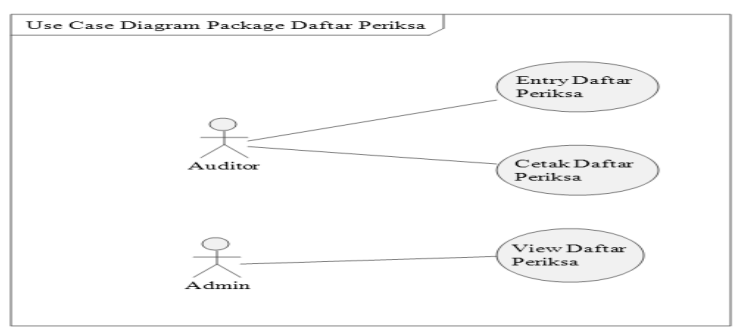

Gambar 9. Use Case Diagram Package Daftar Periksa

e) Use Case Diagram Package Temuan Audit Pada gambar 10 Use Case Diagram Package Temuan Audit terdapat Entry Temuan Audit, View Temuan Audit, Cetak Temuan Audit. Adapun actor pada Use Case Diagram Package Temuan Audit yaitu Admin dan Auditor.

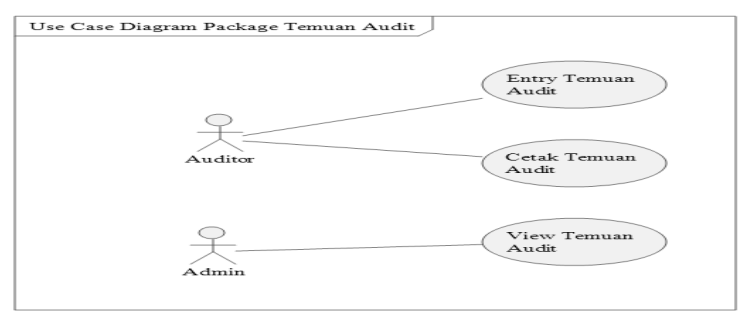

Gambar 10. Use Case Diagram Package Temuan Audit

f) Use Case Diagram Package Resume Audit

Pada gambar 11 Use Case Diagram Package Resume Audit terdapat Entry Resume Audit, View Resume Audit, Cetak Resume Audit. Adapun actor pada Use Case Diagram Package Resume Audit yaitu Admin dan Auditor.

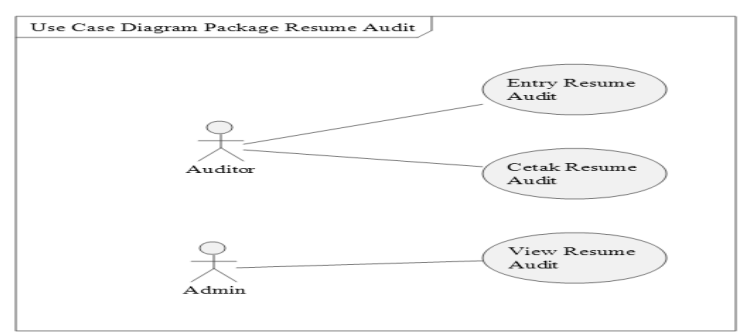

Gambar 11. Use Case Diagram Package Resume Audit

g) Use Case Diagram Package Laporan

Pada gambar 12 Use Case Diagram Package Laporan terdapat Cetak Berita Acara by Periode, Cetak Daftar Periksa by Periode, Cetak Temuan Audit by Periode, Cetak Resume Audit by Periode, Cetak Hasil Audit by Periode. Adapun actor pada Use Case Diagram Package Laporan yaitu Admin.

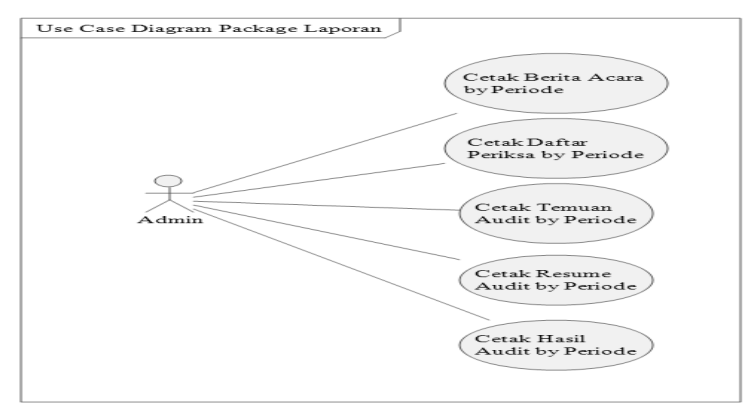

Gambar 12. Use Case Diagram Package Laporan

Pada gambar 13 merupakan Entity Relationship Diagram (ERD). Entity Relationship Diagram (ERD) adalah: "Diagram Hubungan Entitas yang digunakan untuk menggambarkan hubungan antara data store yang ada”.

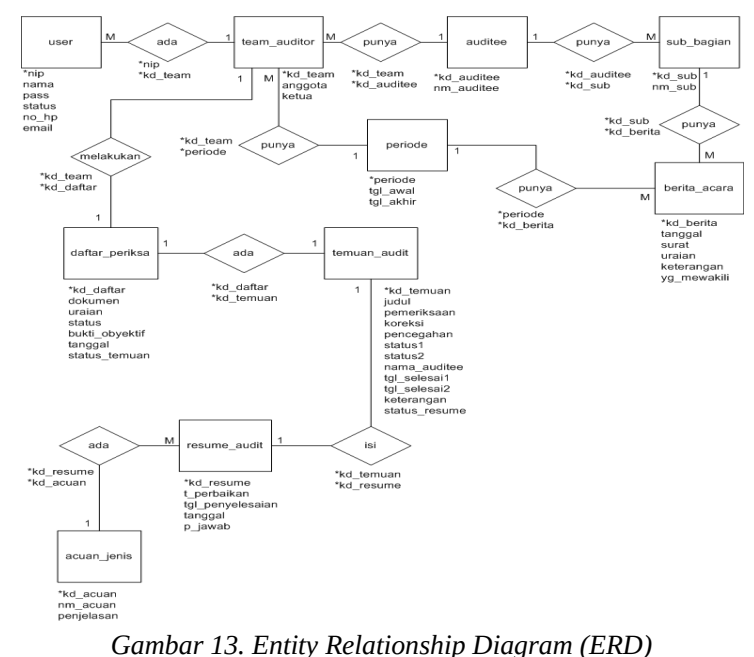

Pada gambar 14 merupakan struktur tampilan menu berdasarkan rancangan sistem usulan berbasis web Sistem Informasi Audit Mutu Internal pada Lembaga Penjaminan Mutu Universitas Budi Luhur sebagai berikut:

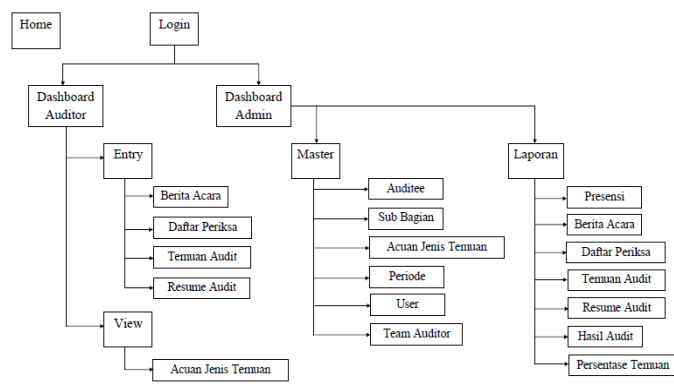

Gambar 14. Struktur Menu

Terdapat 4 (empat) rancangan layar sistem usulan sebagai berikut:

a. Rancangan Layar Berita Acara 
Pada gambar 15 rancangan layar berita acara adalah untuk pengisian data berita acara pada dashboard auditor.

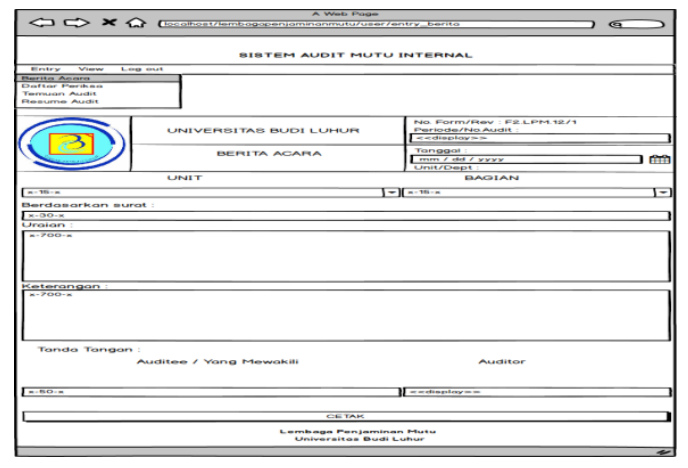

Gambar 15. Rancangan Layar Berita Acara

b. Rancangan Layar Daftar Periksa

Pada gambar 16 rancangan layar daftar periksa adalah untuk pengisian data daftar periksa pada dashboard auditor.

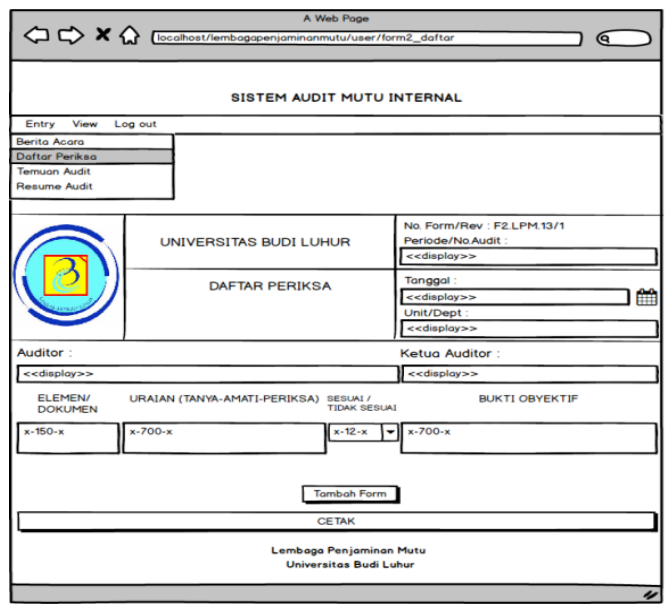

Gambar 16. Rancangan Layar Daftar Periksa

c. Rancangan Layar Temuan Audit

Pada gambar 17 rancangan layar temuan audit adalah untuk pengisian data temuan audit pada dashboard auditor.

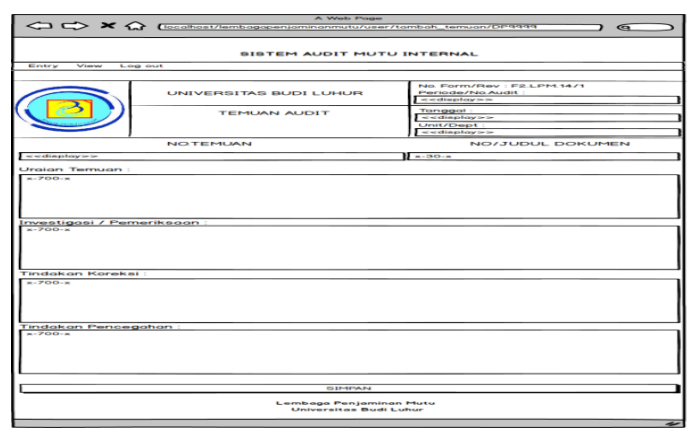

Gambar 17. Rancangan Layar Temuan Audit

d. Rancangan Layar Resume Audit
Pada gambar 18 rancangan layar resume audit adalah untuk pengisian data resume audit pada dashboard auditor.

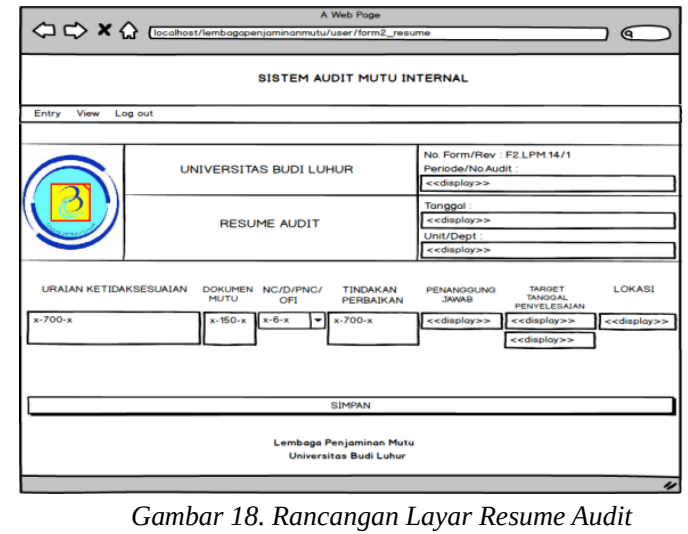

Terdapat 5 (lima) rancangan keluaran sistem sebagai berikut:

a. Rancangan Keluaran Berita Acara

Pada gambar 19 rancangan keluaran berita acara merupakan rancangan keluaran laporan berita acara per periode yang dapat diberikan kepada pihak yang berkepentingan.

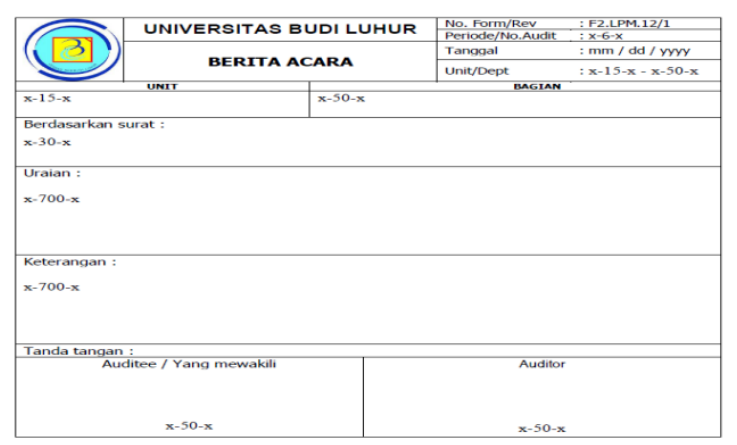

Gambar 19. Rancangan Keluaran Berita Acara

b. Rancangan Keluaran Daftar Periksa

Pada gambar 20 rancangan keluaran daftar periksa merupakan rancangan keluaran laporan daftar periksa per periode yang dapat diberikan kepada pihak yang berkepentingan.

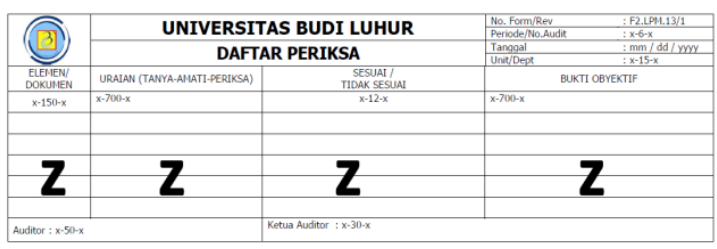

Gambar 20. Rancangan Keluaran Daftar Periksa

c. Rancangan Keluaran Temuan Audit

Pada gambar 21 rancangan keluaran temuan audit merupakan rancangan keluaran laporan temuan audit per periode yang dapat diberikan kepada pihak yang berkepentingan. 


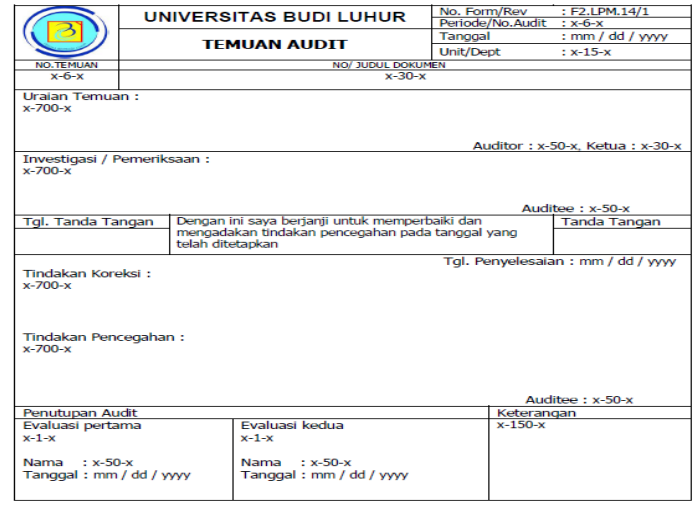

Gambar 21. Rancangan Keluaran Temuan Audit

d. Rancangan Keluaran Resume Audit

Pada gambar 22 rancangan keluaran resume audit merupakan rancangan keluaran laporan resume audit per periode yang dapat diberikan kepada pihak yang berkepentingan.

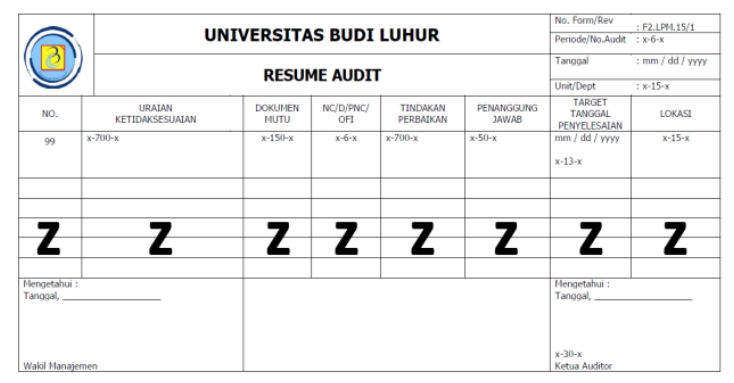

Gambar 22. Rancangan Keluaran Resume Audit

e. Rancangan Keluaran Hasil Audit

Pada gambar 23 rancangan keluaran hasil audit merupakan rancangan keluaran laporan hasil audit per periode yang dapat diberikan kepada pihak yang berkepentingan.

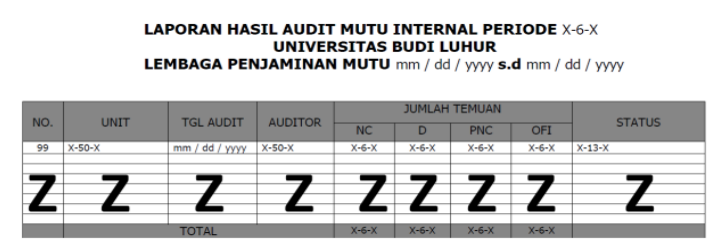

Gambar 23. Rancangan Keluaran Hasil Audit

\section{KESIMPULAN}

Berdasarkan penelitian dan analisa yang telah dilakukan pada Lembaga Penjaminan Mutu Universitas Budi Luhur maka dapat ditarik kesimpulan sebagai berikut:

a. Sistem yang telah dibangun memiliki beberapa fitur. Salah satunya yaitu fitur jenis temuan audit. Fitur ini akan mengurangi kesalahan dalam menentukan jenis temuan audit oleh auditor.

b. Telah tersedia fitur daftar periksa dan resume audit untuk dapat menyelesaikan masalah dalam melakukan proses audit internal yang dalam prosesnya membutuhkan waktu yang relatif lama sehingga rekap laporan audit tidak tepat waktu tersampaikan.

c. Untuk menyelesaikan masalah laporan audit mutu internal yang tidak diselesaikan tepat waktu, peneliti telah membuatkan fitur yang dapat melihat dan mencetak laporan audit mutu internal per periode yang meliputi Cetak Berita Acara by Periode, Cetak Daftar Periksa by Periode, Cetak Temuan Audit by Periode, Cetak Resume Audit by Periode, Cetak Hasil Audit by Periode yang dapat diberikan kepada pihak yang berkepentingan.

d. Agar terlaksananya sistem ini dengan baik, diharapkan adanya proses pelatihan dan kerjasama dengan baik pada semua pihak pada Lembaga Penjaminan Mutu Universitas Budi Luhur yang terkait.

\section{DAFTAR PUSTAKA}

[1] Yakub.Pengantar Sistem Informasi. Yogyakarta: Graha Ilmu. 2012.

[2] Rosa A.S., M. S. Rekayasa Perangkat Lunak Terstruktur dan berorientasi Obyek. Bandung: Informatika. 2013.

[3] Sugiarti, Y. Analisis \& Perancangan UML (Unified Modeling Language) Generated VB.6. Yogyakarta: Graha Ilmu. 2013.

[4] V. Rindengan, A. Lumenta, Y. Rindengan, and I. Engineering, "Rancang Bangun Aplikasi Audit Mutu Akademik Internal Universitas Sam Ratulangi Berbasis Web,” no. 1, pp. 1-6, 2015.

[5] A. Wibowo and A. Azimah, "Rancang Bangun Sistem Informasi Penjaminan Mutu,” pp. 6-7, 2016.

[6] G. W. Wicaksono and A. Al-rizki, "Peningkatan Kualitas Evaluasi Mutu Akademik Universitas Muhammadiyah Malang melalui Sistem Informasi Mutu ( SIMUTU ),” vol. 1, no. 1, pp. 1-8, 2016.

[7] Saeger, A. de, \& Feys, B.TheIshikawa Diagram: Identify problems and take action (First Edit). 2015. 